\title{
Quantified 'Land-use policy options' in forest land evaluation for watershed management
}

\author{
D. C. P. Thalen and A. C. Smiet \\ Department of Botany, Research Institute for Nature Management (RIN), P.O. \\ Box 46, 3956 ZR Leersum, Netherlands
}

Key words: land-use planning, land evaluation, forest planning, watershed management, natural resources conservation

\section{Summary}

A land evaluation for forest land in the upper watershed of the Kali Konto in EastJava, Indonesia, was carried out. Thirteen potential Land Utilization Types (LUTs) were identified and for 155 Land Mapping Units the suitability for each of these LUTs was rated by using the standard land evaluation procedure.

A new concept was then introduced, the quantified 'Land-use policy option', a theoretical combination of LUTs showing quantitatively for the area as a whole the consequences of a particular policy. This quantification is possible because of a further specification of the LUTs in terms of one or more forest management models, specifying produce, labour input and proceeds with projections over a certain range of years. The consequences of extremes such as 'conservation centered', 'population centered', and 'financial return centered' options are shown, but also the data for some 'integrated policy options'.

The method allows the decision maker to base his decisions on quantitative data of the consequences of alternative options. In the Kali Konto case it is shown that theoretically an integrated land-use pattern could be developed in which conservation of the resources is guaranteed while meeting by and large the demands of the local population (fuelwood and light timber) and still have positive direct monetary benefits.

\section{Introduction}

\section{The land evaluation procedure}

Land evaluation for land-use planning was developed as a methodology in the 1970s although the principles applied are much older. Details can be found in Brinkman \& Smyth (1973), FAO (1976) and Beek (1978). The applicability of the method for the various major land-use categories is still under discussion and the scope for improvement is obvious (van Diepen, 1983). Land evaluation for forestry has been discussed in expert meetings, and guidelines are under preparation (Laban, 1981; Gelens, 1983; FAO, 1984). Examples of land evaluation studies for forest land-use planning at a (semi-)detailed scale are still scarce. 
The present paper gives the results of such a study for the Kali Konto upper watershed area, East-Java, Indonesia, emphasizing a newly developed concept: landuse policy options. This concept and its quantitative elaboration through management models was developed to bridge the often existing gaps between the planner (land evaluation specialist, forester), the decision maker and the manager of the land.

The overall approach in land evaluation is summarized in Fig. 1, for details the reader is referred to the above-mentioned sources. In principle land evaluation is a confrontation of supply (the land resources) and demand (the requirements of relevant land-use alternatives). The alternative kinds of land-use are described as Land Utilization Types (LUTs), each with its own physical (vegetation, soil, geomorphological, etc. conditions) and non-physical requirements (capital and labour input, technology level, etc.). The suitability of the area under consideration for the various LUTs is worked out per Land Mapping Unit (LMU). These are relatively homogeneous stretches of land, differing from adjacent units in one or more characteristics such as slope, drainage, vegetation and soil type, etc. In the land evaluation method the LMUs are characterized through their land qualities, usually complex attributes of the land (e.g. accessibility, erodibility, etc.) that are of direct importance for the performance of the land under a specified land-use. For the con-

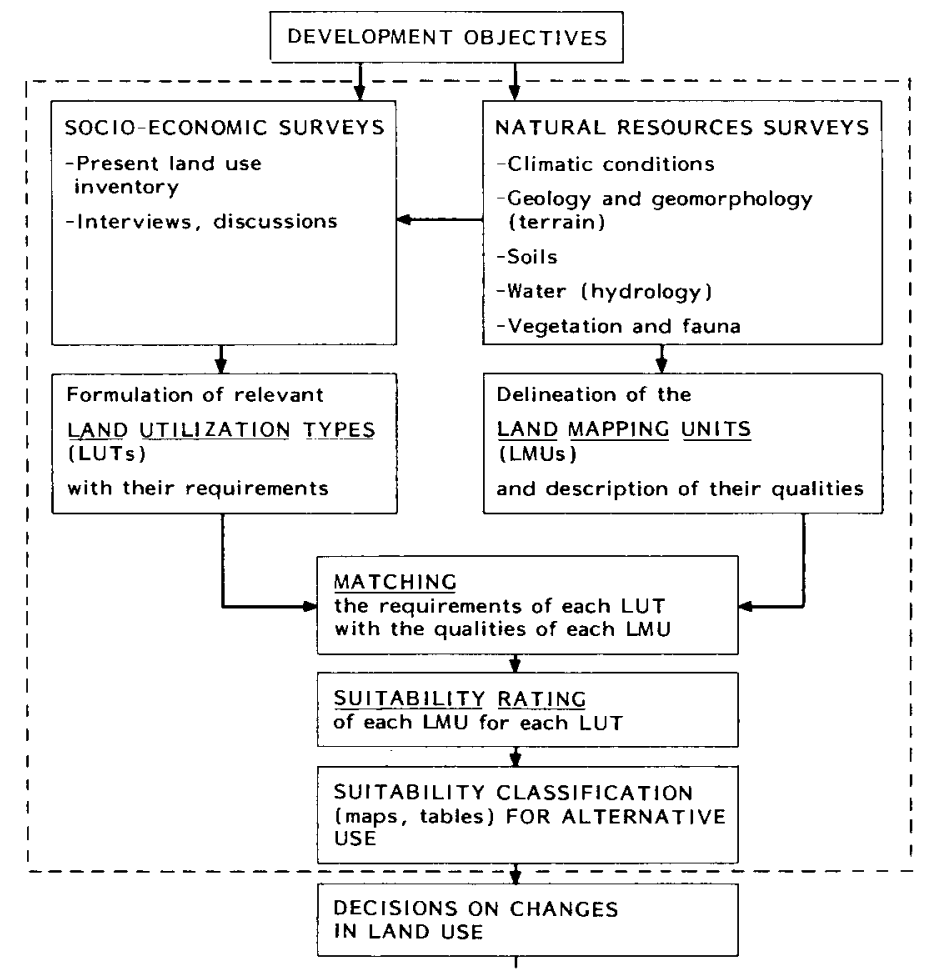

Fig. 1. The procedure and steps in land evaluation. 
frontation of the requirements of the LUTs with the qualities of the LMUs in a matching procedure, conversion tables for each land quality are used. Such tables show the relation between the critical values of the land qualities (e.g. degradation stages of the vegetation) and the different degrees of suitability for each of the LUTs. The final product is a suitability classification giving per LMU the relative suitability in a few classes for each of the LUTs. The quantitative picture can be shown in tables, the spatial picture in maps. After an additional processing, as will be shown hereafter, these land evaluation results can be presented to the decisionmaker in the form of quantified land-use policy options.

\section{Background and aim of the Kali Konto study}

On the densely populated island of Java the remaining natural forests are rapidly deteriorating under the excessive use by a growing population. In half a century (1930-1980) the population of Java and the smaller islands of Madura and Bali increased from 13.5 million to 93.7 million, leading to an average population density of 700 people $\mathrm{km}^{-2}$. The rural population depends for its supply of fuelwood and timber largely upon the natural forests, which at present cover less than $10 \%$ of Java's land surface and which are mainly confined to the mountains. Apart from the wood production, the functioning of the montane forests with respect to the management of soil and water resources is a matter of great concern.

The Kali Konto forest land evaluation study, used in this paper as an example to introduce the concept of quantified land-use policy options, is part of a joint project of the governments of Indonesia and The Netherlands to '. . . establish a planning and management procedure for a study area on Java as an example for all watersheds in densely populated areas of Indonesia'. It was emphasized from the beginning that this should be done in such a way that a proper balance is achieved and can be maintained between the functions of the forest and the needs of the population'. As functions of the forests can be mentioned wood and forage production, and conservation of soil, water and wildlife (plant and animal resources). Apart from forest products, the forest lands can provide labour for the local population. It was realised that a land-use plan for the project area should compromise between these functions and could only be prepared with adequate information on the actual and potential land-use and the socio-economic processes and patterns.

The study was carried out in 1983/84 largely on the basis of data collected from 1979 onwards. The detailed results have been published in a six-volume report and twelve maps (RIN, 1985). The study area of the present paper comprises the 154 $\mathrm{km}^{2}$ forest land of the Kali Konto project area (Fig. 2). The remaining part is covered by other studies (PKK, 1985).

\section{Material and methods}

\section{The study area}

Environmental setting. The $233-\mathrm{km}^{2}$ project area comprises the upper watershed of the Kali Konto river and is situated in the Malang regency in East-Java, about 90 


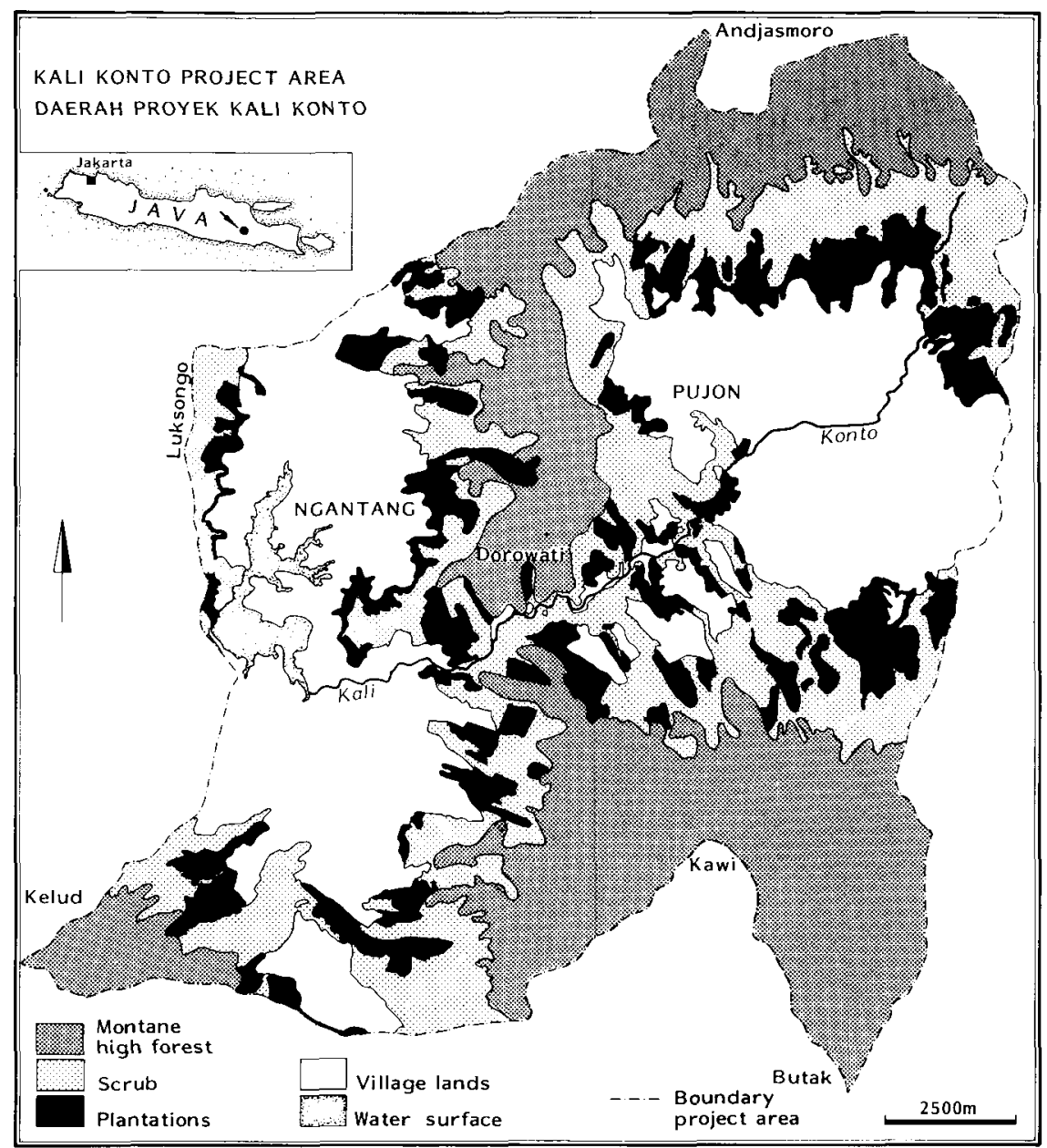

Fig. 2. The Kali Konto project area. The first three legend units comprise the study area.

$\mathrm{km}$ south of Surabaya and $20 \mathrm{~km}$ northwest of Malang (Fig. 2). Three mountain systems of volcanic origin shape the project area into a landscape which can be characterized as an upland plateau surrounded by steeply sloping mountains (Fig. 3). The altitudinal range is from $620 \mathrm{~m}$ to $2800 \mathrm{~m}$ above sea level.

Due to the topographical circumstances, great climatic variations occur within the project area, limiting the use of data from the few fixed weather stations. Temperature and rainfall are governed by the macroscale air movements and the local air movements influenced by orographic effects. Rainfall is seasonally distributed with June, July, August, and September as the driest months (25-55 mm), May and October as months with an intermediate rainfall and November through April as wet months (200-500 mm). Rainfall may be abundant in one year's dry season and 


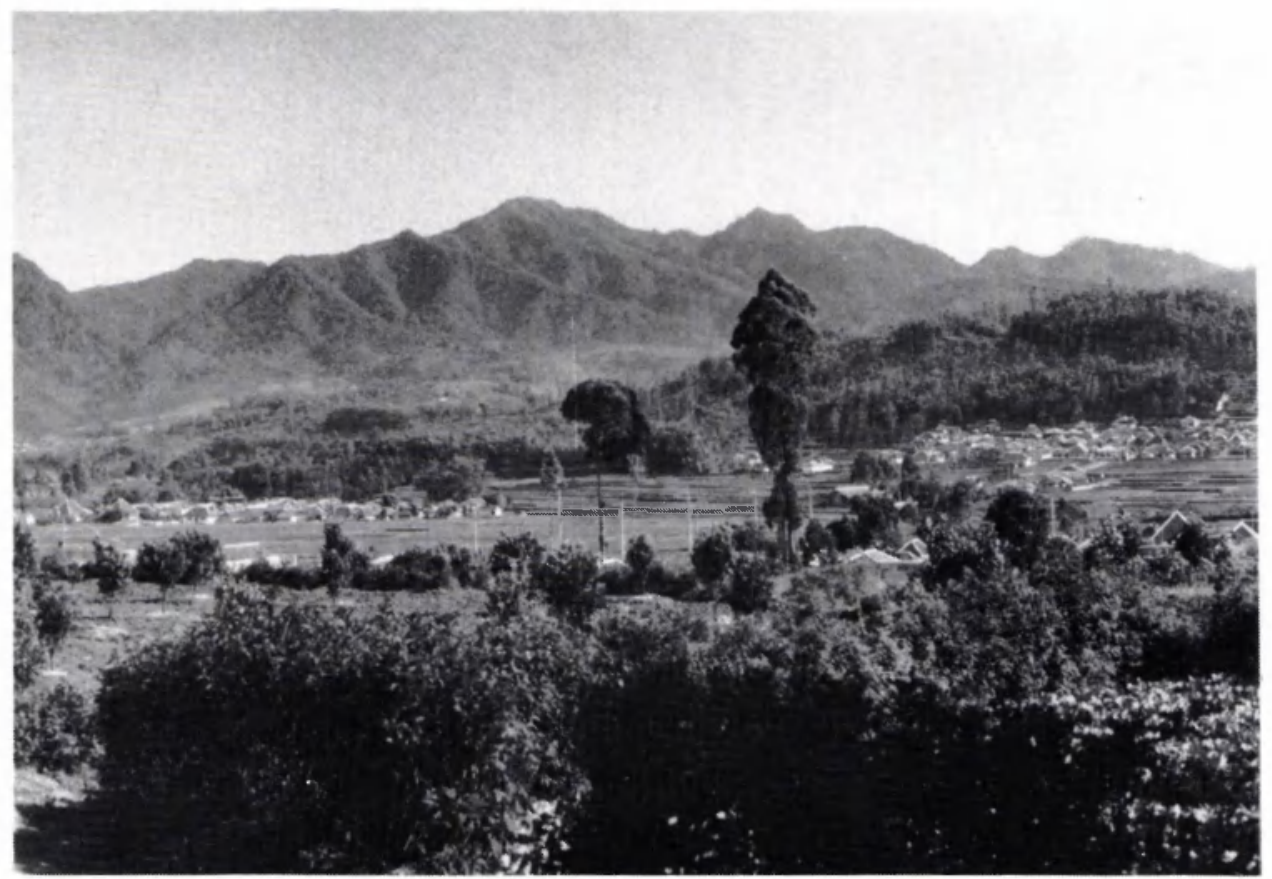

Fig. 3. View of the Kali Konto project area with the village land and, at higher elevation, the forest lands of the Andjasmoro mountain ridges.

zero in another. Mean daily temperatures on a monthly basis are very constant, ranging from $22.7-24.0^{\circ} \mathrm{C}$, with maxima of $28-31{ }^{\circ} \mathrm{C}$ and minima of $17-20{ }^{\circ} \mathrm{C}$. Monthly means of daily evaporation range from 3.1 to $6.4 \mathrm{~mm} \mathrm{day}^{-1}$, sunshine from 3.1 to 6.2 hours day ${ }^{-1}$. Situated at the lowest point in the project area, these Selorejo data are however not representative for the whole area. Average temperatures decrease proportionally with increasing altitude: every $100 \mathrm{~m}$ rise in altitude corresponds with a $0.6{ }^{\circ} \mathrm{C}$ temperature fall. Night time frost has been repeatedly reported from the summits of the Kawi and the Butak, at $2600 \mathrm{~m}$ and $2800 \mathrm{~m}$, respectively.

Geological formations in the project area are typical for inland Java and consist of several volcanic complexes of recent geological origin (van Bemmelen, 1937 , 1952). One volcano, the Kelud, is still active. The volcanic complexes form the bulk of the project area together with interconnecting highland plateaus, raised with eruption material and colluvial sediments.

The landforms can be grouped into five major geomorphological landscape types: (1) valleys, (2) intervolcanic plateaus, (3) foot-slope areas, (4) hilly areas, (5) volcanic mountain areas. The slope class distribution over the forest land for the five major landscapes, as derived from aerial photo interpretation, is shown in Table 1. The soils in the project area have been surveyed extensively. In general, soil types were found to be clearly associated with the recent volcanic nature of the 
Table 1. Distribution of slope classes over the five major landscape types of the forest land area.

\begin{tabular}{lrrrrrr}
\hline Major landscape type & \multicolumn{9}{c}{ Slope class (area in ha) } & & \\
\cline { 2 - 5 } & $<30$ & $30-50$ & $51-70$ & $71-100$ & $>100$ & total \\
& 402 & 199 & 75 & 14 & 4 & 694 \\
Valleys & 526 & 326 & 350 & 194 & 95 & 1491 \\
Intervolcanic plateaus & 581 & 310 & 155 & 79 & 83 & 1208 \\
Footslope areas & 1050 & 1461 & 1853 & 2364 & 765 & 7493 \\
Hilly areas & 372 & 667 & 727 & 1349 & 1439 & 4554 \\
Volcanic mountain areas & 2931 & 2963 & 3160 & 4000 & 2386 & 15440 \\
Total & & & & &
\end{tabular}

region: andosols and cambisols. Soil depth varies with topographical conditions from only a few centimeters on mountain ridges to deposits of many hundreds of meters in the Kali Konto valley. Depending on vegetation, slope length, and soil depth the soils on steep slopes are very susceptible to erosion. Signs of gully erosion and sheet erosion (landslides) occur widespread, especially in the agricultural area.

The Kali Konto is a so-called juvenile river with a large width to depth ratio and an average channel slope of 0.086 . Large boulders of several meters diameter are not uncommon. River flow is very variable and changes quickly: during the wet season the flow may increase from about $2 \mathrm{~m}^{3} \mathrm{~s}^{-1}$ to $100 \mathrm{~m}^{3} \mathrm{~s}^{-1}$ in only a few hours. Mean monthly flow figures show low values in the months from June through November, reflecting the low rainfall in the dry season.

The Kali Konto feeds an artificial storage lake formed in 1970 after completion of the Selorejo dam, which is situated in the westernmost part of the project area. A study of sedimentation in the Selorejo reservoir estimates the total sediment yield of the upper watershed at $275000 \mathrm{~m}^{3}$, equivalent to a soil loss of $1.2 \mathrm{~mm} \mathrm{ha}^{-1} \mathrm{yr}^{-1}$ (Fish, 1983). Dryland agricultural practices on steep slopes and inadequate drainage of roads and residential areas contribute relatively most to the sediment yield.

Population and land-use. The total population of the project area is 92000 . Agriculture and animal husbandry are the main means of subsistence in the $34 \%$ (7886 ha) of privately owned and cultivated land, while the remaining $66 \%$ (15 440 ha, the study area) is state forest land (Table 2).

The bulk of the village land area is located in the accessible plains dissected by the Kali Konto river and many small tributaries. The forest land is situated on the relatively steep surrounding mountains with the plantations at the lower slopes (Fig. 4). It has been calculated that the forest lands are illegally exploited to produce annually $90000 \mathrm{~m}^{3}$ of fuelwood, $30000 \mathrm{~m}^{3}$ of timber and 30000 ton of fodder. It is estimated that some 6000 man-years are spent on these activities and that the livelihood of about 25000 people depends directly or indirectly on this exploitation (PKK, 1985).

Vegetation and fauna. The vegetation in the project area has been greatly influenced by human impact. Most of the original forest has been turned into agricultu- 
Table 2. Areas under the major land-use types in the Kali Konto project area. The boundary between scrub and forest was drawn at $20 \%$ crown cover, determined by aerial photo interpretation.

\begin{tabular}{|c|c|c|c|c|}
\hline Major land-use & Area (ha) & & Area $(\%)$ & \\
\hline Dry-land agriculture & 4540 & & 19.5 & \\
\hline Irrigated agriculture & 1794 & & 7.7 & \\
\hline Village area and home yards & 1268 & & 5.4 & \\
\hline Miscellaneous & 284 & & 1.2 & \\
\hline Subtotal village land & & 7886 & & 33.8 \\
\hline Montane high forest & 6647 & & 28.5 & \\
\hline Plantation forest & 2465 & & 10.6 & \\
\hline Scrub & 6328 & & 27.1 & \\
\hline Subtotal forest land (study area) & & 15440 & & 66.2 \\
\hline Total project area & & 23326 & & 100.0 \\
\hline
\end{tabular}

ral land, forest plantations or scrubland. At present the remaining montane high forest ( $6647 \mathrm{ha}$ ) is confined to high altitudes and inaccessible places, where relicts of the original forest can still be found. Vegetation types here are Elphin forest with Lithocarpus spp. and Vaccinium spp. and Fago-Myrtaceous forest with Podocar-

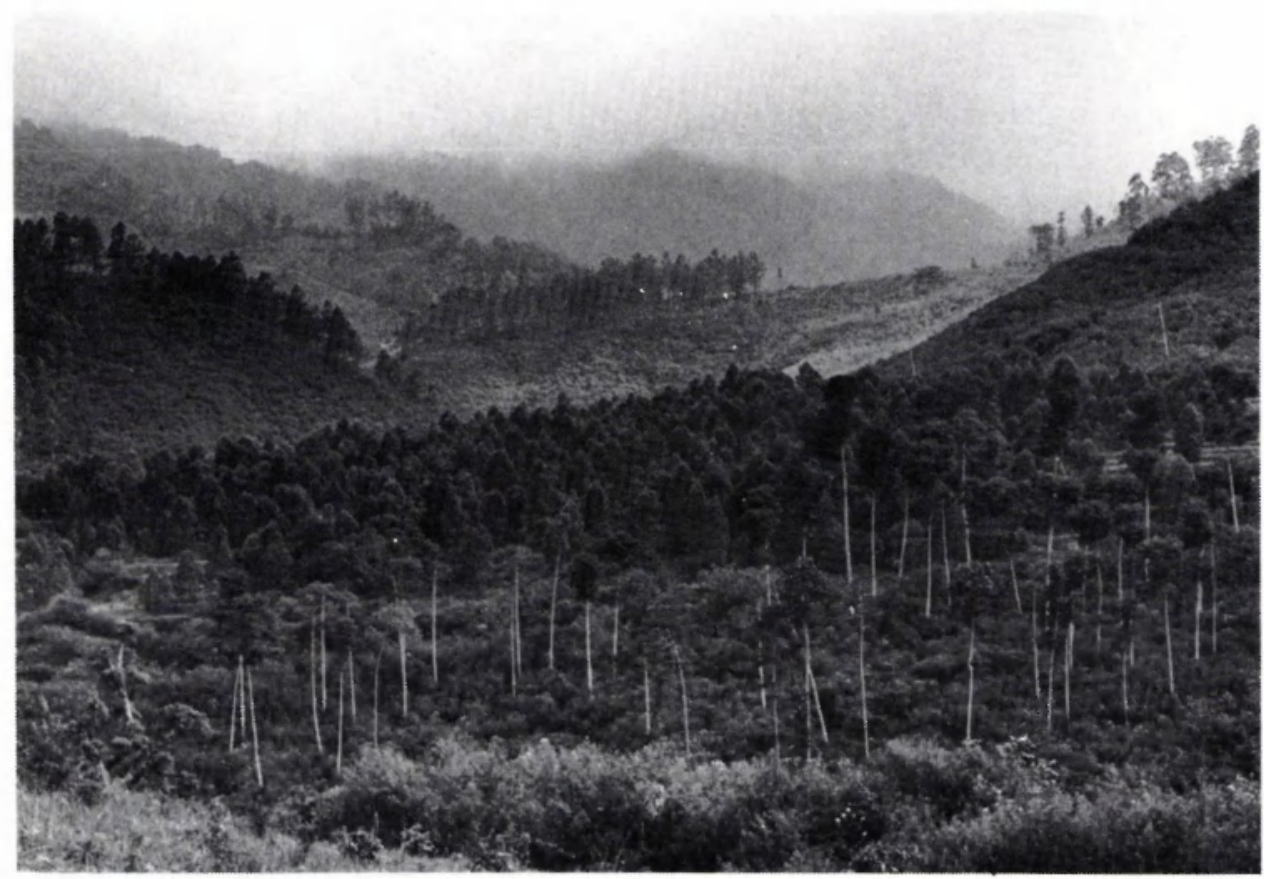

Fig. 4. Plantation forest. Low basal area Eucalyptus in the foreground against denser Pinus stands in the background.

Neth. J. agric. Sci. 33 (1985) 


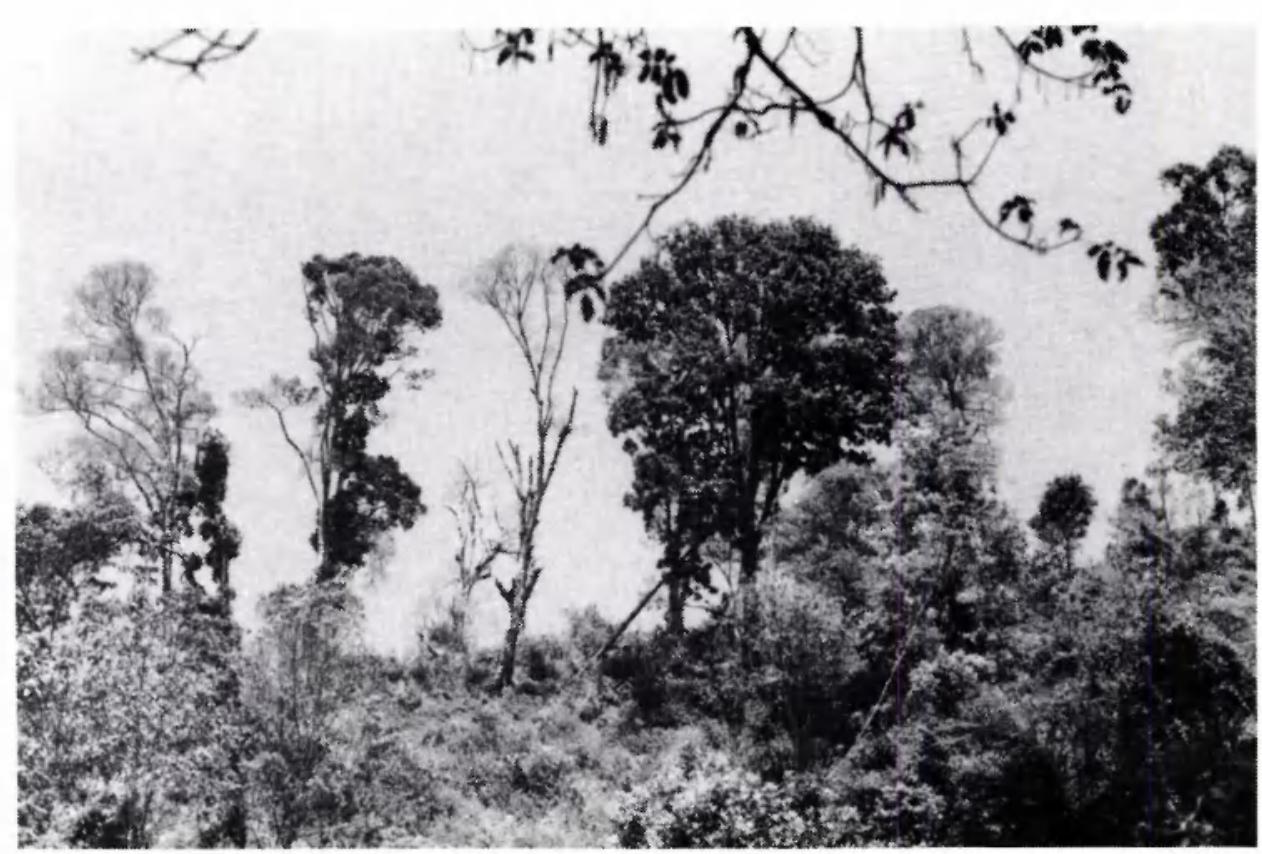

Fig. 5. Natural forest in an advanced stage of degradation: forest structure has lost its homogeneity and trees are now isolated.

pus, Lithocarpus and Eugenia spp. On the lower slopes the original forest has disappeared under the influence of continuous exploitation and been replaced by a scrub vegetation, dominated by the species Eupatorium inulifolium and Lantana camara. The exploitation of the montane forest continues and it is estimated that allowing for increment, a net average quantity of $4-7 \mathrm{~m}^{3} \mathrm{ha}^{-1}$ of wood is annually removed, leading to a gradual degradation of the remaining forest. The exploitation and the resulting degradation process (Fig. 5) is exhaustively described in RIN (1985).

The wildlife in the project area has impoverished drastically in the past hundred years due to increased hunting pressure and human encroachment into the forest. Tiger Panthera tigris, rhinoceros Rhinoceros sondaicus and banteng Bos javanicus have disappeared. At present two species of primates occur (Macaca fascicularis and Presbytis cristata) and the largest mammal species are now the wild boar Sus scrofa and the deer Muntiacus muntjak. The avifauna includes the hornbill Buceros rhinoceros and the parrots Psittacula alexandri and Loriculus vernalis. Occurrence of most animals is restricted to the forest and wild animals - mammals as well as birds - are rarely seen in the cultivated area.

\section{Data base}

For the present land evaluation study no new data collection in the field was con- 
ducted. The following sources were used. For the LUTs and their requirements: knowledge on already existing types of land-use in the area or elsewhere relevant to the study area, (government) reports and publications, and interviews and results of discussions with experts. Detailed information on the socio-economic demands in the project area was derived from PKK (1985). For the LMU land qualities information: literature on geology and hydrology (van Bemmelen, 1937, 1952; Fish, 1983); and resources surveys' data on soils (PKK, 1984) and vegetation (RIN, 1985). The vegetation information was derived from the inventories of the natural forest area and plantation forests. In the natural forest area two survey techniques had been used:

(1) species composition, abundance, and distribution were recorded in sample plots, situated in pre-selected areas and determined according to the Systematic Line-Plot Sampling Method (Mueller-Dombois \& Ellenberg, 1974).

(2) forest structure and forest dynamics were studied with a strip-transect method in which the forest in a selected strip was drawn on scale in a side view and in a ground plan.

A total of 901 survey plots and 35 transect plots, all with an area of $400 \mathrm{~m}^{2}$, were analysed. Six floristic vegetation types were described based on the occurrence of five ecological species groups, determined by computer processing of the plot data. In addition, seven degradation stages were identified from transect material and survey results. Five stages, $\mathrm{A}$ to $\mathrm{E}$, appeared to be typical for the effects of timber cutting and fuelwood collection. Two other stages, D and $G$, were typical for frequent forest fires. The vegetation of the study area was classified according to these degradation stages for which canopy closure, roundwood volume and basal area were quantified. The details of this aspect of the study will be published separately.

To supplement these data, an aerial photo interpretation was done delineating vegetation types for a vegetation map. Another detailed interpretation was made to delineate the LMUs and to provide additional information on land qualities. An already existing orthophotomosaic at scale 1:20000 proved an invaluable document for the maps that were to be prepared.

Land utilization types. Relevant types of land-use for the Kali Konto forest land study area are LUTs related to forestry only. Thirteen were described (Table 3). Some of these were subdivided according to different technology levels. The LUTs can be distinguished on the basis of their objectives: conservation, production, or a combination of these two, with recreation as a separate category, but also on the basis of the technology level required or on the input of labour. Only relevant landuse options were taken into consideration.

Land-mapping units. The LMUs in the present study (in total 155), were delineated on the basis of stereoscopic aerial photo (black and white, panchromatic, 1:20 000) interpretation, whereby geomorphologically determined land-forms were distinguished and used, together with the physiographic soil map, and vegetation information from aerial photographs and field data. Each of the LMUs was described in detail, giving information on: location, major landscape, land-form, soil type, el- 
Table 3. Suitability ratings for 155 LMUs covering the total land area of 15440 ha; figures are the numbers of ha in each suitability class.

\begin{tabular}{rllrrrr}
\hline LUT & Title & Technology & S1 & S2 & S3 & NS \\
1 & Strict protection forest & traditional & 313 & 592 & 1506 & 13029 \\
2 & Natural water conservation forest & traditional & 934 & 4211 & 1073 & 9222 \\
3 & Natural soil conservation forest & traditional & 2371 & 6415 & 2564 & 4090 \\
4 & Natural production forest under & a. traditional & 867 & 656 & 1418 & 12499 \\
& extensive management & b. semi trad. & 408 & 479 & 610 & 13943 \\
& & c. advanced & 39 & - & - & 15401 \\
5 & Natural production forest under & a. traditional & 469 & 194 & 431 & 14346 \\
& intensive management & b. semi trad. & 269 & 200 & 194 & 14777 \\
& & c. semi adv. & - & - & - & 15440 \\
6 & Timber and veneer plantations & d. advanced & - & - & - & 15440 \\
& & a. traditional & 5598 & 2787 & 3119 & 3936 \\
& & b. semie trad. & 2593 & 2341 & 2485 & 8021 \\
7 & Pulpwood plantations & c. semi adv. & 1749 & 1383 & - & 12308 \\
& & a. semi trad. & 2593 & 2341 & 2485 & 8021 \\
8 & Fuelwood plantations & b. semi adv. & 1749 & 1383 & - & 12308 \\
9 & Bamboo plantations & traditional & 5598 & 2787 & 3119 & 3936 \\
10 & Village fuel and timber plantations & traditional & 5082 & 2541 & 2619 & 5198 \\
11 & Agroforestry plantations & traditional & 5598 & 2787 & 3119 & 3936 \\
12 & Soil conservation plantations & traditional & 2646 & 2447 & 2548 & 7799 \\
13 & Recreation forest & traditional & 1287 & 5903 & 5759 & 2500 \\
\hline
\end{tabular}

evation, slope-class distribution, total area, vegetation (in detail), erosion hazard (in four classes) and accessibility. Accessibility was distinguished in internal (within a LMU) and external (to reach a LMU from outside) and defined in four classes (very easy, easy, difficult and very difficult). These classes were determined by aerial photo interpretation, separately for access by foot and by vehicle. Accessibility was considered a function of slope and distance and, in case of access by vehicle, the (unspecified) investment of road construction.

Land suitability rating. The suitability rating of a particular LMU (the fitness of a LMU for a defined use, a LUT, at a defined technology level) depends on the extent to which the values of its land qualities meet the requirements of the LUTs. The land qualities used in the matching procedure for the suitability rating of the LMUs in the present study were:

- external accessibility by foot or vehicle,

- vegetation, taking into account the degradation stages, plantation forest, etc. The following assumptions were made: (1) wherever the present vegetation is plantation forest, this implies a 'not suitable' for any of the natural forest LUTs (1 to 5, Table 3$)$; (2) the present vegetation is not relevant as a quality for any of the plantation LUTs (6 to 12, Table 3),

- slope class as the integrating land characteristic for the qualities internal accessibility and erosion hazard.

Two land qualities, soil fertility and moisture availability, were disregarded be- 
cause: (1) no detailed information on these qualities was available and (2) they were considered relatively irrelevant in comparison with the qualities already incorporated, rather uniform for the forest-land area and not limiting for the forest LUTs considered.

The suitability was assessed in four suitability classes: S1, highly suitable; S2, suitable; S3, marginally suitable; NS, not suitable. The actual assessment was done with conversion tables. The data base allowed a suitability rating at the level of slope classes $(<30 \%, 30-50 \%, 51-70 \%, 71-100 \%,>100 \%)$ within the LMU. After checking the requirements of each LUT with the qualities of the LMU, a final rating of S1, S2, S3 or NS could therefore be assigned to each slope within the LMU. Where several vegetation degradation stages occurred within one LMU, it was assumed that the most degraded stages occurred on the least steep slopes. Compared with the natural forest vegetation types plantation forest was assumed to occur in the most accessible parts of a LMU.

For each LMU a suitability rating form was filled out assigning the number of hectares of the unit to the suitability classes S1, S2, S3 or NS. Depending on slope-class distribution the entire LMU was assigned to one suitability class (if the LMU contained one slope class) or to a maximum of five different suitability classes corresponding with the slope classes. Based on the suitability rating per LMU, maps were prepared for the forest land of the entire project area depicting the spatial suitability pattern for each LUT or combination of LUTs.

\section{Management models}

Land evaluation usually ends with the suitability classification, handed over to the decision-maker in the form of maps and tables and accompanying report (Fig. 1). The results regarding the physical environmental conditions are later further integrated with socio-economic aspects in the course of the land-use planning. In the present study, some further steps were taken to facilitate this procedure. The LUTs were 'translated' in one or more management models, 20 in total, specifying quantitatively produce, labour input, and proceeds with projections over a range of years, assuming sound silvicultural practices (e.g. no illegal exploitation). It will be clear that calculations could only be carried out for those aspects that allow quantification in terms of money or otherwise. For the calculation systems applied standards were set for the inputs and outputs used and for the assumptions regarding labour, specifications of products, cost factors in relation to slope angle, costs of forest activities, etc.

For some utilization types more than one management model was quantified. This is based on the assumption that for these types several relevant technologies and/or rotation periods can be distinguished.

LUT requirements vary greatly per slope class, influencing the proceeds and labour input. The proceeds and labour input were therefore calculated separately for three slope classes. Details on the calculations related to the management models can be found in RIN (1985). 


\section{Quantified land-use policy options}

With the area suitable for particular LUTs and a quantification of these LUTs through the management models (in terms of produce, labour input and proceeds), the quantitative picture of certain land-use policy options can be worked out. Such 'policy options' are land-use alternatives for the area as a whole defined through a combination of the relevant most suitable LUTs and in our study quantified through the management models of these LUTs.

In the Kali Konto study several policy options have been worked out: (1) present land-use, a combination of LUTs and management models simulating as closely as possible the present use pattern, be it under sound silvicultural management; (2) three extreme policy options, viz conservation centered, financial return centered, and population centered; (3) three integrated policy options, using elements from each of the extreme options of (2). It must be emphasized that as far as financial analysis is involved, such analysis only could take into account the direct quantifiable costs and benefits. The indirect costs and benefits, e.g. related to the protective functions of forest which are difficult or impossible to quantify but nevertheless of great importance, had to be left out in this study.

\section{Results and discussion}

\section{Results of the suitability rating}

The number of hectares in each suitability class added for all LMUs per LUT results in an overall picture showing the hectarage of the study area assigned to each of the four suitability classes (Table 3 ). The major conclusions that could be derived from this table in combination with the suitability maps were as follows:

1. Of the total forest land area of 15440 ha, $54 \%$ (8385 ha) is suitable (S1 or S2) for forest plantations in one form or another. A comparison of the suitability maps with the vegetation map showed that virtually the entire present scrub area is suitable for plantation forest.

2. The scope for exploitation of remaining natural forest (LUTs 4 and 5) is very limited. Only some $10 \%$ (1523 ha) of the total forest land area can be regarded suitable (S1 or S2).

3. The areas suitable ( $\mathrm{S} 1$ and $\mathrm{S} 2$ ) for the natural forest 'conservation' LUTs (LUTs 1,2 and 3 ) are not suitable (S3 and NS) for any of the 'exploitation' LUTs. The two types of LUTs (conservation vs exploitation) have contradicting requirements, e.g. as related to slope and external accessibility.

\section{The land-use policy options and their consequences}

In Table 4 the quantitative data for each of the earlier mentioned policy options are shown.

The present land-use can be regarded as a combination of the existing natural water and soil conservation forest (LUTs 6,7 and 8). The produce and proceeds of this option are relatively low because more than $6000 \mathrm{ha}$ (scrub) remain improductive.

The conservation-centered option solely aims at the optimal conservation of natu- 
Table 4. Summary of the produce, labour input and direct benefits for (A) present land-use, (B) three extreme policy options, and $(C)$ three integrated policy options

\begin{tabular}{|c|c|c|c|c|c|c|c|c|c|}
\hline \multicolumn{2}{|c|}{ Policy option } & \multirow[t]{2}{*}{ LUTs* } & \multicolumn{5}{|c|}{ Products $\left(10^{3} \mathrm{~m}^{3} \mathrm{yr}^{-1}\right)$} & \multirow{2}{*}{$\begin{array}{l}\text { Labour } \\
\text { input } \\
\text { (man- } \\
\text { year) }\end{array}$} & \multirow{2}{*}{$\begin{array}{l}\text { Direct benefits } \\
\text { NPW proceeds** } \\
\left(10^{6} \mathrm{Rp} \mathrm{yr}^{-1}\right)\end{array}$} \\
\hline & & & $\begin{array}{l}\text { fuel- } \\
\text { wood }\end{array}$ & poles & $\begin{array}{l}\text { pulp- } \\
\text { wood }\end{array}$ & $\begin{array}{l}\text { light } \\
\text { timber }\end{array}$ & $\begin{array}{l}\text { heavy } \\
\text { timber }\end{array}$ & & \\
\hline A & $\begin{array}{l}\text { Present } \\
\text { land-use }\end{array}$ & $\begin{array}{l}2,3,6 \\
7,8\end{array}$ & 20.5 & 3.8 & 12.8 & 13.4 & 0.0 & 462 & -21.4 \\
\hline B1 & $\begin{array}{l}\text { Conservation- } \\
\text { centered }\end{array}$ & $\begin{array}{l}2,3 \\
6 a\end{array}$ & 25.3 & 18.6 & 0.0 & 52.6 & 24.0 & 975 & +21.5 \\
\hline B2 & $\begin{array}{l}\text { Financial } \\
\text { return }\end{array}$ & $\begin{array}{l}4 \mathrm{a}, 5 \mathrm{~b} \\
6 \mathrm{a}, 7 \mathrm{a}\end{array}$ & 29.8 & 15.4 & 42.8 & 61.3 & 2.9 & 1647 & +543.5 \\
\hline B3 & $\begin{array}{l}\text { Population- } \\
\text { centered }\end{array}$ & $\begin{array}{l}2,3,6 \\
8,11\end{array}$ & 181.9 & 7.3 & 0.0 & 25.9 & 0.0 & 2668 & -16.9 \\
\hline $\mathrm{Cl}$ & $\begin{array}{l}\text { Integrated } \\
\text { (fuelwood, } \\
\text { timber) }\end{array}$ & $\begin{array}{l}2,3 \\
6 \mathrm{a}, 8 \\
11\end{array}$ & 110.3 & 5.5 & 4.8 & 32.7 & 0.0 & 1665 & +172.5 \\
\hline $\mathrm{C} 2$ & $\begin{array}{l}\text { Integrated } \\
\text { (heavy timber) }\end{array}$ & $\begin{array}{l}2,3,6 \mathrm{a} \\
8,11\end{array}$ & 85.3 & 11.9 & 0.0 & 37.8 & 10.7 & 1454 & +270.0 \\
\hline $\mathrm{C} 3$ & $\begin{array}{l}\text { Integrated } \\
\text { (pulpwood) }\end{array}$ & $\begin{array}{l}2,3,6 \mathrm{a} \\
7 \mathrm{a}, 8\end{array}$ & 98.8 & 6.4 & 29.4 & 22.2 & 3.6 & 1446 & +133.7 \\
\hline
\end{tabular}

* See Table 3. Although LUTs may be the same for certain policy options, the management models used to calculate the quantitative data may differ.

** NPW $=$ Net Present Worth in rupiahs (Rp); 1 US \$ equals appr. Rp 1100.

ral resources, such as vegetation, soil and water. The total forest land is managed as protection forest. For this option those LUTs have been chosen that guarantee a long-term conservation of renewable resources. LUTs 2 and 3 comply with this condition, but also plantations with long rotation species (LUT 6). Table 4 shows that compared with other options, labour input and product volume are low and that the overall direct benefits are positive. Although the conservation of natural resources is taken care of (indirect benefits), this option does not sufficiently meet other demands like the supply of wood, or financial return on investment.

In the financial return option, the use and the management of the land aim at maximum financial profit. The composition and management of the forest are geared towards financial return, irrespective of local needs and existing laws and regulations. Only those LUTs have been chosen that give a high financial profit. They include plantations for the production of timber and pulpwood as well as exploitation of natural forest (respectively LUTs 6, 7, 4 and 5). For this option only 8385 ha could be assigned to LUTs, since the remaining 7055 ha appeared unsuited (too steep or inaccessible to provide a positive financial return). Labour input is moderate and the produce is varied and includes a high volume of timber and pulpwood, but a low volume of fuelwood. The overall direct benefits are, as might be expected, very high compared with the other options. Apart from the fact that the needs of the population are not met, the indirect benefits are totally neglected. This 
total neglect of conservation of natural resources will ultimately lead to further problems with erosion, siltation, and water shortage.

In the population-centered option the use and management of the land are aimed at the fulfilment of the needs of the local population with respect to job opportunities (labour input) and consumption of fuelwood and timber. Those LUTs have been chosen that require a high labour input and produce a high volume of fuelwood and light timber. Apart from the LUTs 6, 8 and 11 (timber, fuelwood and agroforestry plantations respectively) the LUTs 2 and 3 have been included because conservation of soil and water is beneficial to the local population and because they can be assigned to areas which are unsuitable for any of the plantation LUTs. Labour input is high, product output of fuelwood is very high (even more than needed in the project area) and the output of poles and light timber is moderately high, enough to meet the demand. The overall direct benefits are slightly negative. This option fulfils the local demand for wood and to some extent the need for conservation but the financial return on investment is negative.

In Table 4 the results of three examples of integrated policy options are also given, using elements from each of the extreme options presented before. The main purpose of this exercise was to illustrate the potential of the forest land to meet various demands from society under an adjusted management policy.

Integration of options was based on the following premises:

- exploitation of the remaining natural forest is undesirable, since it endangers the conservation of resources by destabilizing the already fragile forest ecosystem;

- the output of forest products should as far as possible take into account the needs of the society as a whole and the local population with respect to financial benefits and volume;

- LUTs are only assigned to land with S1 or S2 suitability for that particular LUT; S3 suitability is disregarded;

- the overall direct benefits must be positive;

- long-term conservation of resources should be guaranteed.

The three examples shown present results that fall within the limits set by the mentioned premises. Conservation of resources is guaranteed by choosing the LUTs 2 and 3 (conservation of soil and water by natural forest) on steep and inaccessible mountain slopes and by choosing a LUT with long-rotation plantations (LUT 6: timber and veneer plantations) on steep, but accessible slopes. On the least steep slopes the LUTs 8 and 11 have been chosen (Calliandra plantations and agroforestry respectively) to minimize the risk of erosion.

The options C1, C2 and C3 differ with respect to the following choices: option C1 includes a large amount of heavy timber and light timber in the product output; options $\mathrm{C} 2$ and $\mathrm{C} 3$ include a large amount of heavy timber and pulpwood respectively. All three options guarantee conservation of resources, meet by and large the demands of the local population with respect to fuelwood (assuming some fuelwood production from the village land) and light timber, and have positive direct benefits.

Other examples can be worked out choosing different LUTs and management models. Each will lead to a different output of forest products and direct benefits, 
emphasizing conservation of resources to varying extents and requiring a variable amount of labour input. The outcome of the examples clearly demonstrates that the potential of the forest land leaves enough flexibility for the decision-makers to choose an acceptable compromise, meeting at the same time the demands of the local population in terms of fuelwood and timber, the requirements for proper conservation of soil and water and leaving intact the yet remaining natural montane high forest.

In the present study the concept of quantified land-use policy options is applied to the results of a forest land evaluation. Application to land evaluation studies with other major land-use types, such as crop production and rangeland is now being considered.

\section{References}

Beek, K. J., 1978. Land evaluation for agricultural development. ILRI Publication No 23. ILRI, Wageningen, Netherlands, $333 \mathrm{pp}$.

Bemmelen, R. W. van, 1937. The volcano-tectonic structure of the residency of Malang (East Java). De Ingenieur in Nederlands Indië 9: 159-172.

Bemmelen, R. W. van, 1952. De geologische geschiedenis van Indonesië. Van Stockum, The Hague, Netherlands.

Brinkman, R. \& A. J. Smyth (Eds.), 1973. Land evaluation for rural purposes. ILRI Publication No 17. ILRI, Wageningen, Netherlands, $116 \mathrm{pp}$.

Diepen, C. A. van, 1983. Evaluating land evaluation. Annual Report 1982. International Soil Museum, Wageningen, Netherlands, p. 13-29.

FAO, 1976. A framework for land evaluation. Soils Bulletin No 32. FAO, Rome, $73 \mathrm{pp}$. Also published as ILRI Publication No 22. ILRI, Wageningen, Netherlands, $87 \mathrm{pp}$.

FAO, 1984. Land evaluation for forestry. FAO Forestry Paper No 48. FAO, Rome, 123 pp.

Fish, I. L., 1983. Reservoir sedimentation study, Selorejo, East Java. Hydrologic Research Report No OD 51, January 1983.

Gelens, H. F., 1983. Land evaluation for forestation. In: K. F. Wiersum (Ed.), Strategies and designs for afforestation, reforestation and tree planting. Pudoc, Wageningen, Netherlands, p. 219-230.

Laban, P. (Ed.), 1981. Proceedings of the workshop on land evaluation for forestry. ILRI Publication No. 28. ILRI, Wageningen, Netherlands, $355 \mathrm{pp}$.

Mueller-Dombois, D. \& H. Ellenberg, 1974. Aims and methods of vegetation ecology. John Wiley \& Sons, New York/Chichester.

PKK, 1984. Soil and soil conditions Kali Konto upper watershed, East Java. Malang, Indonesia, August 1984. $179 \mathrm{pp}$.

PKK, 1985. General watershed plan for the Kali Konto upper watershed. Final Report, second phase. Malang, Indonesia, April 1985.

RIN, 1985. Evaluation of forest land Kali Konto upper watershed, East Java. Final Report. Vol. I-VI + 12 maps. Research Institute for Nature Management, Leersum, Netherlands. 